\title{
Role of bevacizumab in juvenile onset recurrent respiratory papillomatosis
}

\author{
Abdul Wadood Mohammed* \\ Department of ENT, King Faisal University, Al Ahsa, Kingdom of Saudi Arabia
}

\begin{abstract}
Juvenile-onset recurrent respiratory papillomatosis is a childhood disease notorious for its propensity for recurrence. The children are put through the trauma of repeated surgical procedures affecting the physical and emotional quality of life. Many adjuvant therapies are tried to prevent recurrence of the disease after surgical treatment. Bevacizumab is a monoclonal antibody against vascular endothelial growth factor, which has been recently added to the armamentarium of adjuvant therapy. The present study tries to review the various studies in English literature evaluating the role of bevacizumab in Juvenile-onset recurrent respiratory papillomatosis.
\end{abstract}

\section{Introduction}

Juvenile-onset recurrent respiratory papillomatosis (JORRP) is a chronic infection of viral etiology affecting the upper aerodigestive tract characterized by proliferative lesions over the mucosa. It is due to human papilloma infections acquired from the birth canal of the mother. Even though it has more predilections for the larynx, it can present at any site in the respiratory tract $[1,2]$. The disease is usually benign, but often has a high chance of recurrence, which is usually attributed to incomplete surgical removal of the causative virus. Malignant transformation has been reported to occur in long-standing cases [3].

To prevent recurrence adjuvant therapy is advised after definitive surgical treatment. Many agents are suggested for as adjuvant therapy including cidofovir, SGN-00101, interferon, indole-3-carbinole, cis-retinoic acid, mumps vaccine, HspE7, photodynamic therapy etc. There has been evidence that vascular endothelial growth factor receptor plays an important role in the development of recurrent respiratory papillomatosis. Bevacizumab is a recombinant monoclonal immunoglobulin antibody, which inhibits the biologic activity of human vascular endothelial growth factor there by preventing receptor activation. The present study tries to review the English literature regarding the role of bevacizumab in JORRP.

\section{Methodology}

A comprehensive literature review was done in PubMed using the medical terms juvenile onset recurrent respiratory papillomatosis AND Bevacizumab. That article which was general discussion, nonEnglish language and off-topic were removed. The articles, which dealt with the same topic in the references of these articles, were included in the study (Figure 1).

\section{Results}

The initial search in PubMed using medical terms juvenile onset recurrent respiratory papillomatosis and Bevacizumab revealed 10 articles. After initial scrutiny, 4 articles were included in the study after excluding one german article, 3 off topic articles, and 2 general discussions. One article of the similar topic was included in the study for the references. In the end, there were 5 articles for study (Table 1).

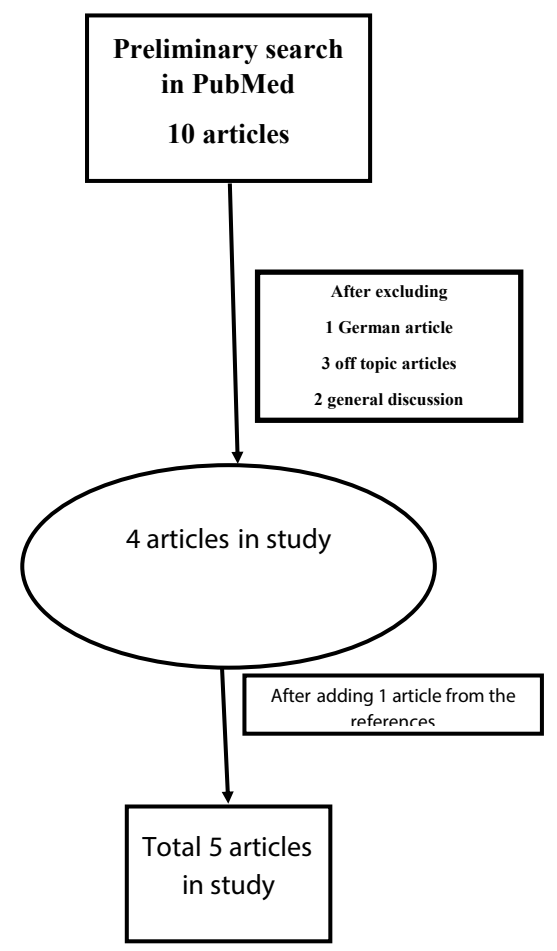

Figure 1:

Correspondence to: Dr. Abdul Wadood Mohammed, Department of ENT, College of Medicine, King Faisal University, Al Ahsa, Kingdom of Saudi Arabia, E-mail: wadood_abd@yahoo.co.in,Wadood83@gmail.com

Key words: juvenile onset recurrent respiratory papillomatosis, bevacizumab, adjuvant therapy

Received: May 17, 2016; Accepted: May 30, 2016; Published: June 03, 2016 
Table 1. Studies included in the review. KTP- potassiun titanyl phosphatePR- Partial response, VGPR- very good partial response, PVQOL -Pediatric Voice Quality of Life.

\begin{tabular}{|c|c|c|c|c|}
\hline S. No & Author & Study & Mode of delivery & Outcome measures \\
\hline 1 & Mohr et al. [5] & $\begin{array}{l}\text { Prospective } \\
\text { observational }\end{array}$ & systemic & $\begin{array}{l}\text { PR/VGPF in } 5 / 5 \text { patient } \\
\text { Reduction of number of intervention from } 18 \text { to } 1\end{array}$ \\
\hline 2 & Sidell et al. [6] & $\begin{array}{l}\text { Prospective } \\
\text { observational }\end{array}$ & Sublesional + KTP Laser & $\begin{array}{l}\text { Increased time period between interventions } \\
58 \% \text { improvement in Derkay score }\end{array}$ \\
\hline 3 & Roger et al. [8] & $\begin{array}{l}\text { Prospective } \\
\text { observational }\end{array}$ & Intralesional + KTP Laser & $\begin{array}{l}\text { Median duration of time between surgical procedures increased by } 5.9 \text { weeks }(\mathrm{P}=.002) \text {. } \\
\text { Median number of procedures/year decreased by } 4(\mathrm{P}=.002) . \\
\text { Derkay staging decreased by } 6(\mathrm{P}=.03) \\
\text { Median total PVRQOL score increased by } 25.5(\mathrm{P}=.02) \\
\text { Median Emotional PVRQOL score increased by } 11.3(\mathrm{P}=.047) \\
\text { Median Physical PVRQOL score increased by } 14.3(\mathrm{P}=.047) .\end{array}$ \\
\hline 4 & Zeitel et al. [7] & $\begin{array}{l}\text { Prospective } \\
\text { observational }\end{array}$ & Sublesional + KTP Laser & $\begin{array}{l}3 / 20 \text { no disease } \\
16 / 20 \text { reduced disease } \\
1 / 20 \text { increased disease } \\
35 \% \text { did not require further Laser procedure compared to } 15 \% \text { in laser only group }\end{array}$ \\
\hline 5 & Maturo et al. [9] & $\begin{array}{l}\text { Prospective } \\
\text { observational }\end{array}$ & $\begin{array}{l}\text { Microdebrider+KTP Laser + } \\
\text { Intralesional }\end{array}$ & $\begin{array}{l}\text { Mean surgical procedure per month was reduced in all } 3 \text { patient. } \\
\text { Derkay score reduced in } 1 \text { patient. } \\
\text { PVRQOL increased in } 2 \text { patient. }\end{array}$ \\
\hline
\end{tabular}

\section{Discussion}

Juvenile-onset recurrent respiratory papillomatosis is benign, but troublesome disease due to its propensity for recurrence and need for multiple surgical procedures. To reduce recurrences the patient is started on adjuvant therapy. Many agents have been tried for adjuvant therapy. Bevacizumab is a monoclonal antibody against vascular endothelial growth factor (VEGF). Studies have shown strong expression of VEGF-A mRNA was noted in the squamous epithelium of papillomas and VEGFR-1 and VEGFR-2 were noted in the endothelial cells of the underlying vessels [4].

In a Prospective observational study by Mohr et al. [5], immediate and sustained response was seen after systemically administering bevacizumab was observed in five patients with progressive JORRP who underwent multiple local procedures. Another significant observation was that 4 out of 5 patients did not require any further surgical intervention. One patient underwent laryngectomy due to malignant transformation. They recorded the response of the lesion to treatment during the administration of the drug and those patients who showed relapse on discontinuation of the drug showed a response on retreatment. Sidell et al. [6] demonstrated a median $58 \%$ improvement in 5 patients who underwent sub epithelial injections of bevacizumab along with KTP LASER ablation. Another study by Zeitel et al. [7] combining sub lesional bevacizumab with KTP laser found that there was a significant response to the disease. Out of 20 patients who received 4 injections, 3 had no discernible disease, 16 patients had a partial response and 1 patient had increased disease. 7 of the patients did not require any further laser coagulation. In a prospective case series by Roger et al. [8], intra lesional injection of bevacizumab alone produced an average increase of 5.9 weeks in the time interval between the injections, the median number of surgical interventions were decreased by 4 , physical pediatric voice-related quality of life was increased by 14.3 and median emotional pediatric voice-related quality of life was increased by 11.3. In another study by Maturo et al. [9], after treating the patient with microdebrider pulsed KTP laser and intralesional bevacizumab, all children showed increased time interval between prodecures.

A prospective study by Best et al. [10] in 43 patients to assess the possible complications of intralesional bevacizumab found that there were no complications associated with laryngeal injection of the drug.

\section{Conclusion}

The review concludes that there is ample evidence to suggest that bevacizumab is a good agent for adjuvant therapy of JORRP. It is either effective when used systemically or intralesionally alone or along with microdebrider or KTP Laser. However, the adequate duration of treatment has to be evaluated as the disease relapsed when the drug was stopped in some studies. More studies are needed comparing the efficacy of different agents used in adjuvant therapy.

\section{References}

1. Reeves WC, Ruparelia SS, Swanson KI, Derkay CS, Marcus A, et al. (2003) National registry for juvenile-onset recurrent respiratory papillomatosis. Arch Otolaryngol Head Neck Surg 129: 976-982. [Crossref]

2. Gélinas JF, Manoukian J, Côté A (2008) Lung involvement in juvenile onset recurrent respiratory papillomatosis: a systematic review of the literature. Int $J$ Pediatr Otorhinolaryngol 72: 433-452. [Crossref]

3. Gorgoulis V, Rassidakis G, Karameris A, Giatromanolaki A, Barbatis C, Kittas C (1994) Expression of p53 protein in laryngeal squamous cell carcinoma and dysplasia: possible correlation with human papillomavirus infection and clinicopathological findings. Virchows Arch 425: 481-489. [Crossref]

4. Rahbar R, Vargas SO, Folkman J, McGill TJ, Healy GB, et al. (2005) Role of vascular endothelial growth factor-A in recurrent respiratory papillomatosis. Ann Otol Rhinol Laryngol 114: 289-295. [Crossref]

5. Mohr M, Schliemann C, Biermann C, Schmidt LH, Kessler T, et al. (2014) Rapid response to systemic bevacizumab therapy in recurrent respiratory papillomatosis. Oncol Lett 8: 1912-1918. [Crossref]

6. Sidell DR, Nassar M, Cotton RT, Zeitels SM, de Alarcon A (2014) High-dose sublesional bevacizumab (avastin) for pediatric recurrent respiratory papillomatosis. Ann Otol Rhinol Laryngol 123: 214-221. [Crossref]

7. Zeitels SM, Barbu AM, Landau-Zemer T, Lopez-Guerra G, Burns JA, Friedman AD, et al. (2011) Local Injection of bevacizunab(Avastin) and angiolytic KTP laser treatment of reccurent respiratory papillomatosis of vocal folds: a prospective study. Ann Otol Rhinol Laryngol 120: 627-634. [Crossref]

8. Rogers DJ, Ojha S, Maurer R, Hartnick CJ (2013) Use of adjuvant intralesional bevacizumab for aggressive respiratory papillomatosis in children. JAMA Otolaryngol Head Neck Surg 139: 496-501. [Crossref]

9. Maturo S, Hartnick CJ (2010) Use of 532-nm pulsed potassium titanyl phosphate laser and adjuvant intralesional bevacizumab for aggressive respiratory papillomatosis in children: initial experience. Arch Otolaryngol Head Neck Surg 136: 561-565. [Crossref]

10. Best SR, Friedman AD, Landau-Zemer T, Barbu AM, Burns JA, et al. (2012) Safety and dosing of bevacizumab (avastin) for the treatment of recurrent respiratory papillomatosis. Ann Otol Rhinol Laryngol 121: 587-593. [Crossref]

Copyright: (C2016 Mohammed AW. This is an open-access article distributed under the terms of the Creative Commons Attribution License, which permits unrestricted use, distribution, and reproduction in any medium, provided the original author and source are credited. 